ДМИТРИЕВА П. Р.

СМЫСЛОЖИЗНЕННЫЕ ОРИЕНТАЦИИ У ЛЮДЕЙ С РАЗНЫМ УРОВНЕМ СТРАХА СМЕРТИ

РоссиЙскИй пСИХОЛОГИЧЕСКИЙ ЖУРнАл, 2020, Т. 17, № 3, 5-17. doi: 10.21702/rpj.2020.3.1

ОБЩАЯ ПСИХОЛОГИЯ, ПСИХОЛОГИЯ ЛИЧНОСТИ, ИСТОРИЯ ПСИХОЛОГИИ

УдК 159.9.072.43 doi: 10.21702/rpj.2020.3.1

Оригинальная научная статья

\title{
Смысложизненные ориентации у людей с разным уровнем страха смерти
}

\author{
Полина Р. Амитриева \\ Южный фелеральный университет, г. Ростов-на-Аону, Российская ФеАерация \\ E-mail: misspolls@gmail.com \\ ORCID ID: https://orcid.org/0000-0002-4590-2089
}

\begin{abstract}
Аннотация
Введение. Целью статьи стало описание смысложизненных ориентаций у АюАей с разным уровнем страха смерти. Статья содержит теоретический обзор феномена смерти в контексте исслеАований смысложизненных ориентаций. Основная проблема заключается в неАостаточной разработанности в отечественной психологической науке проблемы отношения к смерти и его взаимосвязи с ценностно-смысловой сорерой. Автором Аоказывается актуальность изучения феномена смерти в контексте изучения осмысленности жизни и фрормирования осознанного отношения к ней. Новизна исслеАования заключается в изучении взаимосвязи межАу осмысленностью и уАОвлетворенностью жизни с отношением к смерти у АюАей, А^я которых вопрос смерти не является актуальным в их текущей жизненной ситуации.

Методы. В разделе описываются методы проведенного эмпирического исслеАования, в котором Использовались психоАиагностические метоАики (опросник «УАовлетворенность жизнью», методика А. А. Аеонтьева «Смысложизненные ориентации», «Профриль аттитьюАов по отношению к смерти» в аАаптации Т. А. Гавриловой) и метоАы математической статистики Аля обработки полученных Аанных (метолы описательной статистики, коэфрфициент линейной корреляции Пирсона, квартилирование, критерий Манна-Уитни).

Результаты. Раздел солержит Аанные эмпирического исследования, проведенного на выборке из 148 человек в возрасте 18-50 ^ет. Автор приволит Аанные, согласно которым ^юАи с высоким уровнем страха смерти характеризуются более низким уровнем жизненной вКАЮченности И осмысленности жизни.

ОбсужАение результатов. Благодаря полученным результатам была выявлена связь межАу уровнем страха смерти и смысложизненными ориентациями, выявлены значимые различия межАу АюАьми с разными уровнями страха смерти, закАючающиеся в различном уровне осмысленности жизни, вкАюченности в жизнь, отношения к смерти. В зак^ючение Аелается вывоА о том, что отношение к смерти напрямую связано с осмысленностью и уАовлетвореннОСТЬЮ ЖИзНИ.
\end{abstract}

\section{КАючевые слова}

смысложизненные ориентации, страх смерти, нейтральное принятие, приближающее принятие, избегание, избавляющее принятие, танатическая тревога, суициАология, удовлетворенность жизнью, осмысленность жизни 
ДМИТРИЕВА П. Р.

СМЫСЛОЖИЗНЕННЫЕ ОРИЕНТАЦИИ У ЛЮДЕЙ С РАЗНЫМ УРОВНЕМ СТРАХА СМЕРТИ

Российский психологИчЕский ЖУРнАл, 2020, Т. 17, № 3, 5-17. doi: 10.21702/rpj.2020.3.1

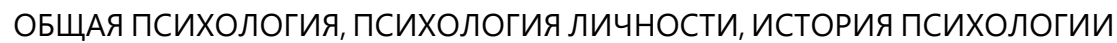

\section{Основные положения}

> отношение к смерти связано с уровнем осмысленности и уловлетворенности жизнью; > $ю$ Юи с высоким уровнем страха смерти характеризуются более низким уровнем осмыс^енности и уАовлетворенности жизнью, чем АЮАи с низким уровнем страха смерти;

> у $ю$ юй с высоким уровнем страха смерти Аоминирует также отношение приближающего принятия - т. е. веры в загробную жизнь, в то время как у Аюлей с низким уровнем страха смерти Аоминирующим типом отношения является нейтральное принятие, т. е. принятие смерти как неизбежной ступени в развитии человека.

\section{Для цитирования}

Дмитриева, П. Р. (2020). Смысложизненные ориентации у людей с разным уровнем страха смерти. Российский психологический журнал, 17(3), 5-17. doi: 10.21702/rpj.2020.3.1

Дата получения рукописи: 15.05 .2020

Дата окончания рецензирования: 08.07.2020 Дата принятия к публикации: 15.07.2020

\section{Введение}

В последние десятилетия активно развивается экзистенциальное направление исследований в психологии. Получаемые результаты имеют не только большую научную значимость, но также важнейшее значение для психотерапевтической практики. Широко распространены исследования отношения к жизни, определения смысложизненных стратегий и ориентаций, метафорической репрезентации образа мира и себя в нем (Абульханова-Славская, 1991; Леонтьев, 2003; Абдулгалимова, 2011; Абакумова, Ермаков и Рудакова, 2014; Коромыслов, 2019; и др.). Однако понятие жизни неразрывно связано с понятием смерти. Стоит отметить, что проблематика смерти в работах отечественных и зарубежных исследователей представлена, как правило, работами в области паллиативной медицины, теории горя, суицидологии (КюблерРосс, 2001; Гнездилов, 2002; Липецкий, 2013; Чистопольская и др., 2014; Баканова, 2015; Кукина, 2015; Пинегина, 2017; и др.). Тем не менее, смерть - событие, с которым сталкивается каждый человек, причем не только в случае тяжелой болезни или сложной жизненной ситуации. Таким образом, очевидна проблема несоответствия узкой специализации исследования феномена смерти в рамках отдельных групп населения, для которых вопрос смерти актуален в текущей жизненной ситуации (тяжелая болезнь - своя или близких; попытка суицида; потеря близких; старение; пребывание в ситуации, несущей угрозу жизни; и др.), объективной широте этого феномена и охвату абсолютно всех категорий населения, независимо от возраста, состояния здоровья, уровня благосостояния и любых других факторов.

Вопрос смерти - один из важнейших экзистенциальных вопросов, которым задаются люди не только в период сложных жизненных ситуаций. И особенности ответа на него могут оказывать влияние на все сферы жизни человека, в частности ценностно-смысловой, однако по большей части исследование этого вопроса представлено в смежных с психологией областях (антропологии, социологии, культурологии) и недостаточно разработано в отечественной психологической науке в контексте исследования отношения к смерти людей вне сложной жизненной ситуации. Тем не менее, анализ работ отечественных и зарубежных исследователей дает основание для изучения феномена смерти в контексте смысложизненных ориентаций. 
ДМИТРИЕВА П. Р.

СМЫСЛОЖИЗНЕННЫЕ ОРИЕНТАЦИИ У ЛЮДЕЙ С РАЗНЫМ УРОВНЕМ СТРАХА СМЕРТИ

РОССИЙСКИЙ пСИХОЛОГИЧЕСКИЙ ЖУРнАл, 2020, Т. 17, № 3, 5-17. doi: 10.21702/rpj.2020.3.1

ОБЩАЯ ПСИХОЛОГИЯ, ПСИХОЛОГИЯ ЛИЧНОСТИ, ИСТОРИЯ ПСИХОЛОГИИ

Согласно ряду исследователей - психологов, социологов, антропологов, культурологов (Арьес, 1992; Гроф, 2002; Wong, 2013; Горьковая и Баканова, 2014; Кленина и Песков, 2015; Мохов, 2016; Солдатова и Жукова, 2018) - именно отношение к смерти является маркером зрелости личности и общества, в котором приняты те или иные типы отношения к смерти и их символическая репрезентация в виде ритуалов, обрядов, памятников и символов. Отсюда рождается вывод о том, что показателем психологической зрелости и здоровья является отношение к смерти в виде принятия.

В то же время, выдвинутая Greenberg, Pyszczynski, \& Solomon (1986) теория управления страхом смерти предполагает наличие и поддержание в обществе страха смерти через ее игнорирование и отрицание, что обусловливает осознание человеком ценности жизни и делает смерть инструментом регламентации жизни общества. Таким образом, речь идет о том, что приемлемым типом отношения к смерти для здорового человека является избегание мыслей о смерти. Эта идея находит отражение и в ряде современных исследований (Корнев и Смирнов, 2018; Андриевская, 2017).

Психоаналитическая сторона придерживается мнения о присутствии у здорового человека страха смерти, который, однако, может лежать в основе большинства неврозов и невротических состояний.

Франкл (1990), Арьес (1992), Фейфел (2001), Фромм (2006) и другие исследователи говорят о том, что современное общество отрицает смерть, в то время как осознание смерти является сильнейшим стимулом жизни. Таким образом, подавляя мысли о смерти, человек лишает себя «катализатора, без которого радость и энтузиазм утрачивают интенсивность и глубину» (Фромм, 2006, с. 250).

Таким образом, возникает вопрос, какой тип отношения к смерти является более «здоровым» и соответствует более зрелому состоянию личности, более высокому уровню осмысленности и осознанности. Научная новизна исследования состоит в изучении в рамках психологической науки особенностей отношения к смерти у категории людей, для которых вопрос смерти не является актуальным в настоящий момент в контексте их жизненной ситуации и их смысложизненных ориентаций.

Общим для всех указанных работ является признание страха как основной эмоции по отношению к смерти. Отсюда рождается вопрос: связаны ли страх смерти и его признание и принятие с уровнем осознанности, осмысленности и удовлетворенности жизнью.

Исходя из вышеизложенного, была сформулирована гипотеза: страх смерти связан с уровнем осмысленности и удовлетворенности жизнью.

Целью исследования стало выявление наличия или отсутствия связи между страхом смерти и уровнем осмысленности и удовлетворенности жизнью и, при ее наличии, определение типа отношения к смерти, соответствующего более высокому уровню осмысленности и удовлетворенности жизнью.

\section{Методы}

В качестве методов исследования было выбрано анкетирование с помощью психодиагностических методик (опросник «Удовлетворенность жизнью» (Мельникова, 2004), методика Д. А. Леонтьева «Смысложизненные ориентации» (Леонтьев, 2006), «Профиль аттитьюдов по отношению к смерти» в адаптации Т. А. Гавриловой (Гаврилова, 2011)) и методы математической статистики (методы описательной статистики, коэффициент линейной корреляции 
ДМИТРИЕВА П. Р.

СМЫСЛОЖИЗНЕННЫЕ ОРИЕНТАЦИИ У ЛЮДЕЙ С РАЗНЫМ УРОВНЕМ СТРАХА СМЕРТИ

Российский психологИЧЕский ЖУРнАл, 2020, Т. 17, № 3, 5-17. doi: 10.21702/rpj.2020.3.1

ОБЩАЯ ПСИХОЛОГИЯ, ПСИХОЛОГИЯ ЛИЧНОСТИ, ИСТОРИЯ ПСИХОЛОГИИ

Пирсона, квартилирование, критерий Манна -Уитни).

В исследовании приняли участие 148 человек в возрасте 18-50 лет (из них 89 девушек (61\%), 57 юношей (39\%), средний возраст респондентов - 25,9 лет, стандартное отклонение - 6,8), граждане Российской Федерации, жители Ростова-на-Дону и Ростовской области. С помощью критерия Манна - Уитни было проведено сравнение мужчин и женщин по шкалам «Профиля аттитьюдов по отношению к смерти». Значимых различий обнаружено не было, что свидетельствует об отсутствии разницы в отношении к смерти у представителей разных полов и позволяет объединить их в одну группу. Корреляций с возрастом и значимых отличий между возрастными группами обнаружено не было, что также позволяет объединить респондентов в одну группу.

\section{Результаты}

С помощью коэффициента линейной корреляции Пирсона были выявлены прямые и обратные значимые связи шкалы «страх смерти» со шкалами: «жизненная включенность» $(R=-0,259)$, «беспокойство о будущем» $(R=-0,381)$, «общая удовлетворенность жизнью» $(R=-0,330)$, «цели» $(R=-0,272)$, «процесс» $(R=-0,224)$, «результат» $(R=-0,234)$, «локус контроля - Я» $(R=-0,372)$, «локус контроля - жизнь» $(R=-0,280)$, «осмысленность жизни» $(R=-0,309)$, «избегание темы смерти» $(R=0,550)$, «нейтральное принятие» $(R=-0,266)$, «приближающее принятие» $(R=0,469)$, «избавляющее принятие» $(R=0,300)$ - связи при уровне значимости $p=0,01$, а также связь со шкалой «разочарование в жизни» $(R=-0,211)$ при уровне значимости $p=0,05$. Из всех типов отношения к смерти, представленных в «Профиле аттитьюдов по отношению к смерти», страх смерти показал наибольшее количество связей по силе и уровню значимости с другими шкалами.

Исходя из этого, с помощью процедуры квартилирования выборка была поделена на три группы в зависимости от результатов по шкале «страх смерти» (опросник «Профиль аттитьюдов по отношению к смерти»):

- группа с низким уровнем страха смерти (37 человек);

- группа с высоким уровнем страха смерти (32 человека);

- группа со средним уровнем страха смерти (79 человек).

Выделенные группы попарно сравнивались с помощью критерия Манна -Уитни, благодаря чему были получены следующие результаты (табл. 1).

Между группами с низким и средним уровнем страха смерти значимые различия наблюдаются по шкалам «беспокойство о будущем» (уровень значимости $p=0,01$ ), «локус контроля - Я» (уровень значимости $р=0,05)$, «избегание темы смерти», «нейтральное принятие», «приближающее принятие» (уровень значимости $p=0,01$ ).

Между группами со средним и высоким уровнем страха смерти были обнаружены значимые различия по шкалам «жизненная включенность», «беспокойство о будущем», «общая удовлетворенность жизнью» (уровень значимости $p=0,05)$, «цели», «локус контроля - Я», «осмысленность жизни», «избегание темы смерти», «приближающее принятие» (уровень значимости $\mathrm{p}=0,01)$.

Между группами с низким и высоким уровнем страха смерти были обнаружены значимые различия почти по всем шкалам: «жизненная включенность» (уровень значимости $p=0,01)$, «разочарование в жизни» (уровень значимости $\mathrm{p}=0,05)$, «беспокойство о будущем», «общая удовлетворенность жизнью», «цели», «процесс», «результат», «локус контроля - Я», «локус 
ДМИТРИЕВА П. Р.

СМЫСЛОЖИЗНЕННЫЕ ОРИЕНТАЦИИ У ЛЮДЕЙ С РАЗНЫМ УРОВНЕМ СТРАХА СМЕРТИ

РоссиЙскИй пСИХОЛОГИЧЕСКИЙ ЖУРнАл, 2020, Т. 17, № 3, 5-17. doi: 10.21702/rpj.2020.3.1

ОБЩАЯ ПСИХОЛОГИЯ, ПСИХОЛОГИЯ ЛИЧНОСТИ, ИСТОРИЯ ПСИХОЛОГИИ

контроля-жизнь», «осмысленность жизни», «избегание темы смерти», «нейтральное принятие», «приближающее принятие», «избавляющее принятие» (уровень значимости р = 0,01).

\begin{tabular}{|c|c|c|c|c|}
\hline \multicolumn{5}{|c|}{$\begin{array}{l}\text { Таблица } 1 \\
\text { Результаты попарного сравнения знач } \\
\text { с помощью критерия Манна -Уитни }\end{array}$} \\
\hline Шкa^a & Значение & $\begin{array}{c}\text { Высокий- } \\
\text { низкий уровень }\end{array}$ & $\begin{array}{c}\text { Средний- } \\
\text { низкий уровень }\end{array}$ & $\begin{array}{c}\text { Высокий- } \\
\underline{\text { средний уровень }}\end{array}$ \\
\hline \multirow{2}{*}{$\begin{array}{l}\text { Жизненная } \\
\text { включенность }\end{array}$} & U Манна -Уитни & 380.000 & 1357.000 & 881.000 \\
\hline & $\begin{array}{l}\text { Асимптотическая } \\
\text { знач. (2-сторонн.) }\end{array}$ & 0.010 & 0.532 & 0.012 \\
\hline \multirow{2}{*}{$\begin{array}{l}\text { Разочарование } \\
\text { в жизни }\end{array}$} & U Манна-Уитни & 409.500 & 1181.500 & 1122.000 \\
\hline & $\begin{array}{l}\text { Асимптотическая } \\
\text { знач. (2-сторонн.) }\end{array}$ & 0.026 & 0.093 & 0.351 \\
\hline \multirow[b]{2}{*}{ Уста^Ость От Жизни } & U Манна -Уитни & 437.500 & 1330.000 & 1029.500 \\
\hline & $\begin{array}{l}\text { Асимптотическая } \\
\text { знач. (2-сторонн.) }\end{array}$ & 0.056 & 0.423 & 0.120 \\
\hline \multirow{2}{*}{$\begin{array}{l}\text { Беспокойство } \\
\text { о будущем }\end{array}$} & U Манна -Уитни & 281.500 & 1010.000 & 910.000 \\
\hline & $\begin{array}{l}\text { Асимптотическая } \\
\text { знач. (2-сторонн.) }\end{array}$ & 0.000 & 0.007 & 0.019 \\
\hline \multirow{2}{*}{$\begin{array}{l}\text { Общая } \\
\text { уАОвлетворенность }\end{array}$} & U Манна -Уитни & 316.500 & 1196.000 & 882.500 \\
\hline & $\begin{array}{l}\text { Асимптотическая } \\
\text { знач. (2-сторонн.) }\end{array}$ & 0.001 & 0.112 & 0.012 \\
\hline \multirow{2}{*}{ Цель } & U Манна -Уитни & 327.500 & 1176.500 & 832.500 \\
\hline & $\begin{array}{l}\text { Асимптотическая } \\
\text { знач. (2-сторонн.) }\end{array}$ & 0.001 & 0.091 & 0.005 \\
\hline \multirow{2}{*}{ Процесс } & U Манна -Уитни & 377.000 & 1229.500 & 972.000 \\
\hline & $\begin{array}{l}\text { Асимптотическая } \\
\text { знач. (2-сторонн.) }\end{array}$ & 0.010 & 0.169 & 0.057 \\
\hline
\end{tabular}


ДМИТРИЕВА П. Р.

СМЫСЛОЖИЗНЕННЫЕ ОРИЕНТАЦИИ У ЛЮДЕЙ С РАЗНЫМ УРОВНЕМ СТРАХА СМЕРТИ

РОССИЙСКИЙ ПСИХОЛОГИЧЕСКИЙ ЖУРНАЛ, 2020, Т. 17, № 3, 5-17. doi: 10.21702/rpj.2020.3.1

ОБЩАЯ ПСИХОЛОГИЯ, ПСИХОЛОГИЯ ЛИЧНОСТИ, ИСТОРИЯ ПСИХОЛОГИИ

\begin{tabular}{|c|c|c|c|c|}
\hline \multirow{2}{*}{ Результат } & U Манна-Уитни & 357.000 & 1182.000 & 992.500 \\
\hline & $\begin{array}{l}\text { Асимптотическая } \\
\text { знач. (2-сторонн.) }\end{array}$ & 0.005 & 0.097 & 0.076 \\
\hline \multirow[b]{2}{*}{ ^окус Контро^я -Я } & U Манна-Уитни & 253.500 & 1073.000 & 758.000 \\
\hline & $\begin{array}{l}\text { Асимптотическая } \\
\text { знач. (2-сторонн.) }\end{array}$ & 0.000 & 0.021 & 0.001 \\
\hline \multirow{2}{*}{$\begin{array}{l}\text { Аокус Контроля - } \\
\text { жизнь }\end{array}$} & U Манна-Уитни & 321.500 & 1144.000 & 966.500 \\
\hline & $\begin{array}{l}\text { Асимптотическая } \\
\text { знач. (2-сторонн.) }\end{array}$ & 0.001 & 0.060 & 0.052 \\
\hline \multirow{2}{*}{$\begin{array}{l}\text { Общая } \\
\text { осмысленность }\end{array}$} & U Манна -Уитни & 309.500 & 1184.500 & 858.500 \\
\hline & $\begin{array}{l}\text { Асимптотическая } \\
\text { знач. (2-сторонн.) }\end{array}$ & 0.001 & 0.101 & 0.008 \\
\hline \multirow{2}{*}{$\begin{array}{l}\text { Избегание темы } \\
\text { смерти }\end{array}$} & U Манна-Уитни & 175.000 & 770.500 & 788.000 \\
\hline & $\begin{array}{l}\text { Асимптотическая } \\
\text { знач. (2-сторонн.) }\end{array}$ & 0.000 & 0.000 & 0.002 \\
\hline \multirow{2}{*}{$\begin{array}{l}\text { Нейтральное } \\
\text { принятие }\end{array}$} & U Манна-Уитни & 296.500 & 863.000 & 1187.500 \\
\hline & $\begin{array}{l}\text { Асимптотическая } \\
\text { знач. (2-сторонн.) }\end{array}$ & 0.000 & 0.000 & 0.617 \\
\hline \multirow{2}{*}{$\begin{array}{l}\text { Приближающее } \\
\text { принятие }\end{array}$} & U Манна-Уитни & 181.500 & 802.000 & 798.500 \\
\hline & $\begin{array}{l}\text { Асимптотическая } \\
\text { знач. (2-сторонн.) }\end{array}$ & 0.000 & 0.000 & 0.002 \\
\hline \multirow{2}{*}{$\begin{array}{l}\text { Избав^яющее } \\
\text { принятие }\end{array}$} & U Манна-Уитни & 378.000 & 1029.000 & 1110.500 \\
\hline & $\begin{array}{l}\text { Асимптотическая } \\
\text { знач. (2-сторонн.) }\end{array}$ & 0.010 & 0.010 & 0.317 \\
\hline $\begin{array}{l}\text { Примечание: полу } \\
\text { группами. }\end{array}$ & ным шрифтом об & ны обн & ные значим & Іичия межАу \\
\hline
\end{tabular}


ДМИТРИЕВА П. Р.

СМЫСЛОЖИЗНЕННЫЕ ОРИЕНТАЦИИ У ЛЮДЕЙ С РАЗНЫМ УРОВНЕМ СТРАХА СМЕРТИ

РоссиЙскИй пСИХОЛОГИЧЕСКИЙ ЖУРнАл, 2020, Т. 17, № 3, 5-17. doi: 10.21702/rpj.2020.3.1

Результаты сравнения средних значений по шкалам каждого из опросников представлены в виде гистограмм (рис. 1-3).

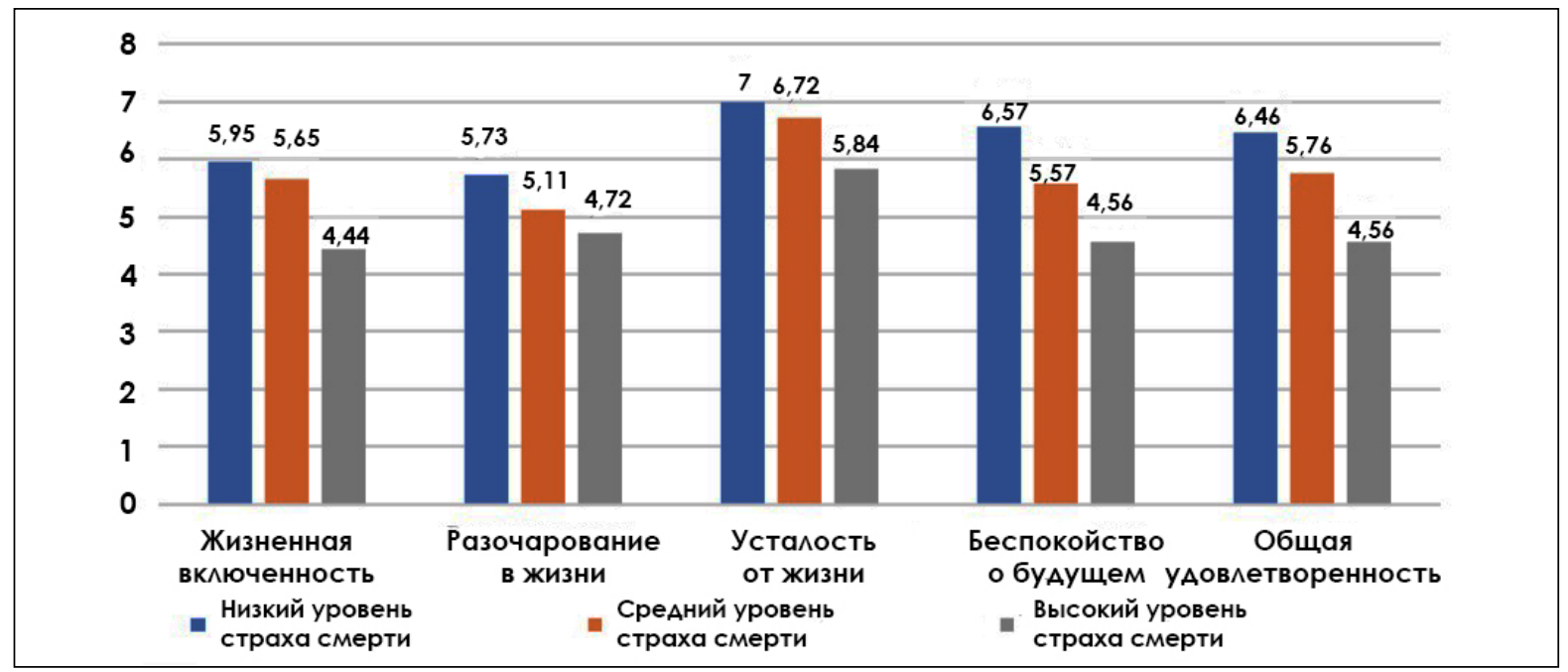

Рисунок 1. Гистограмма шкал опросника «УАовлетворенность жизнью»

Примечание: значимые различия обнаружены по шкалам «жизненная включенность», «общая удовлетворенность» (группы с низким и средним уровнем страха смерти значимо отличаются от группы с высоким уровнем страха смерти, $p=0,01$ ), «разочарование в жизни» (группа с низким уровнем страха смерти значимо отличается от группы с высоким уровнем страха смерти, $p=0,26)$, «беспокойство о будущем» (все группы значимо отличаются друг от друга, $p=0,01) ;$ по шкале «усталость от жизни» значимых отличий обнаружено не было.

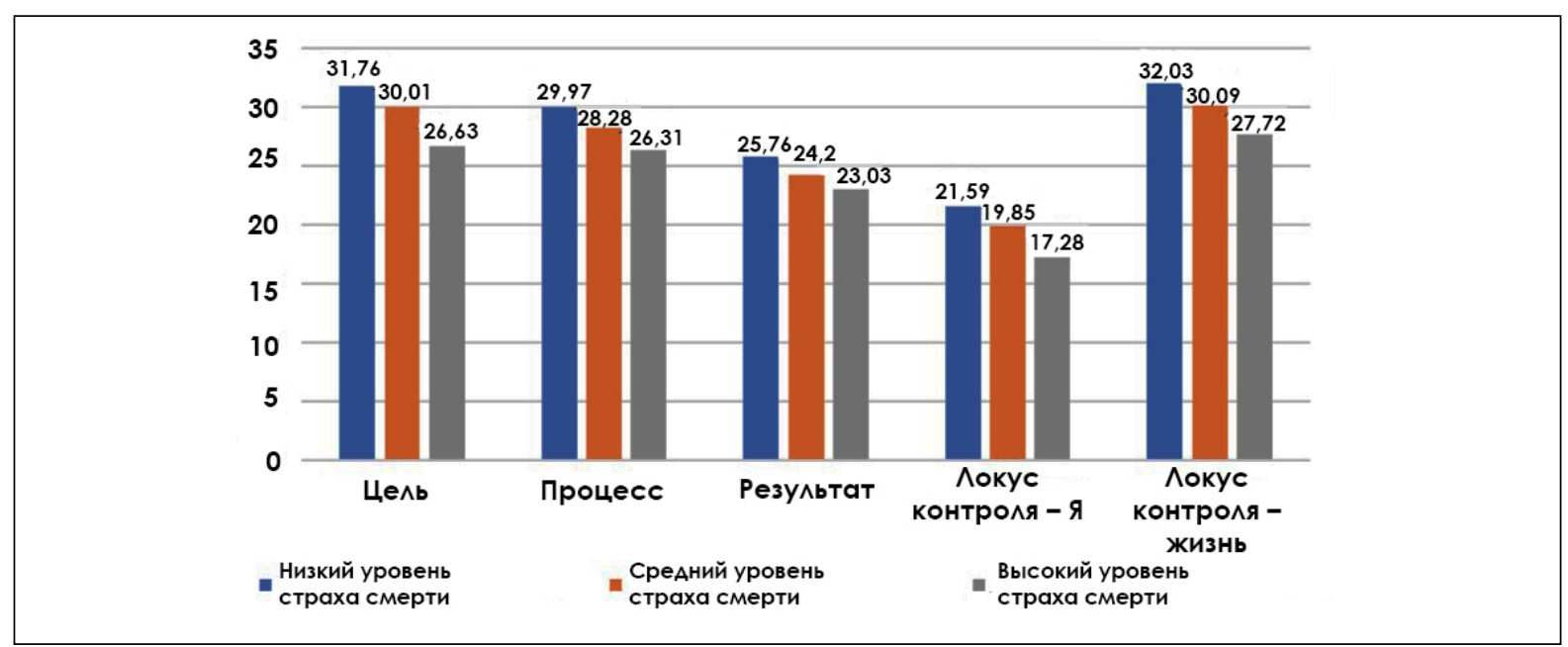

Рисунок 2. Гистограмма шкал опросника «Смысложизненные ориентации»

Примечание: значимые различия обнаружены по шкалам «цель» (группы с низким и средним уровнем страха смерти значимо отличаются от группы с высоким уровнем страха смерти, $p=0,001)$, «процесс», «результат», «локус контроля - жизнь» (группа с низким уровнем страха смерти значимо отличается от группы с высоким уровнем страха смерти, $p=0,01$ ), «локус контроля -Я» (все группы значимо отличаются друг от друга, $p=0,001$ ). 
ДМИТРИЕВА П. Р.

СМЫСЛОЖИЗНЕННЫЕ ОРИЕНТАЦИИ У ЛЮДЕЙ С РАЗНЫМ УРОВНЕМ СТРАХА СМЕРТИ

РосСиЙский псИХолоГИЧЕСКИй ЖУРнАл, 2020, Т. 17, № 3, 5-17. doi: 10.21702/rpj.2020.3.1

\section{ОБЩАЯ ПСИХОЛОГИЯ, ПСИхОЛОГИЯ ЛИЧНОСтИ, ИстОРИЯ ПСИхОЛОГИИ}

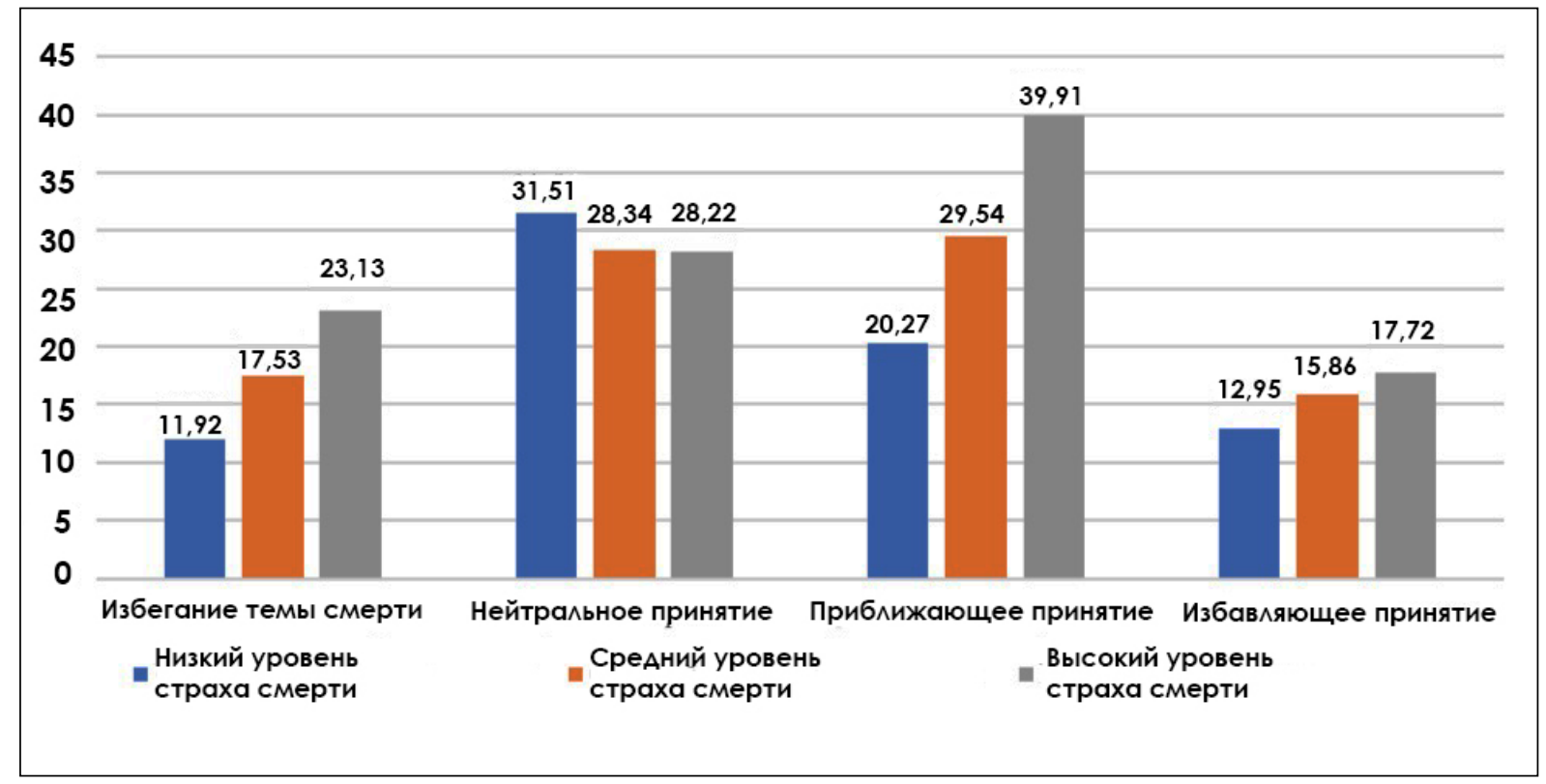

Рисунок 3. Гистограмма шкал опросника «Профри^ь аттитьюАов по отношению к смерти»

Примечание: значимые различия обнаружены по шкалам «нейтральное принятие», "избавляющее принятие» (группы с высоким и средним уровнем страха смерти значимо отличаются от группы с низким уровнем страха смерти, $p=0,001)$, «избегание темы смерти» $(p=0,01)$, «приближающее принятие» (все группы значимо отличаются друг от друга, $p=0,001)$.

Исходя из полученных результатов, люди с высоким уровнем страха смерти характеризуются наиболее низким уровнем жизненной включенности как ощущения насыщенности и полноты жизни, активности, наличия и выраженности позитивных эмоциональных состояний. При этом люди с высоким уровнем страха смерти в меньшей степени испытывают разочарование от жизни как субъективное ощущение ее безрезультатности и беспокойство по поводу будущего как тревожных ожиданий неблагоприятных событий. Это может быть обусловлено низким уровнем жизненной включенности и осмысленности жизни, что влечет за собой отношения приближающего и избавляющего принятия смерти. Согласно авторам методики, последний тип отношения к смерти выражает тенденции к суицидальному и аутоагрессивному поведению.

Схожие данные имеются в исследовании Hayes, Ward, \& McGregor (2016), связывающие неудовлетворенность жизнью, снижение ориентаций на будущее, пессимистическое отношение к жизни и танатическую тревогу. По всем шкалам опросника «Смысложизненные ориентации» результаты группы с высоким уровнем страха смерти оказались значимо ниже, чем у других групп, что показывает общую сниженность осмысленности жизни в субъективном переживании ее цели, процесса, результата, собственной способности и возможностей контроля и управления жизнью. При этом ведущим типом отношения к смерти, помимо страха, является приближающее принятие, что характеризуется П. Т. П. Вонгом и коллегами как вера в приятную «жизнь после смерти», т. е. смерть воспринимается как переход в другую жизнь (Wong, Reker, \& Gesser, 1994). Таким образом, подтверждается мнение Feifel \& 
ДМИТРИЕВА П. Р.

СМЫСЛОЖИЗНЕННЫЕ ОРИЕНТАЦИИ У ЛЮДЕЙ С РАЗНЫМ УРОВНЕМ СТРАХА СМЕРТИ

РоссийскИй псИХологИчЕскИй жУРнАл, 2020, Т. 17, № 3, 5-17. doi: 10.21702/rpj.2020.3.1

Branscomb (1973) и Желателева (2016) о том, что вера в загробную жизнь способствует невротизации и увеличению страха смерти как события, которое может привести к страданиям.

Полученные результаты представляют особый интерес, поскольку, согласно исследованиям Корнева и Смирнова (2018), Андриевской (2017), вера в загробную жизнь является одним из сильных методов борьбы со страхом смерти и соответствует нейтральному принятию смерти, а согласно исследованиям Harding, Flannelly, Weaver, \& Costa (2005) и Nazarzadeh, Sarokhani, \& Sayehmiri (2015), вера в существование Бога и в загробную жизнь отрицательно коррелирует с уровнем страха смерти. Результаты по шкале «приближающее принятие» наглядно представлены на графике (рис. 4).

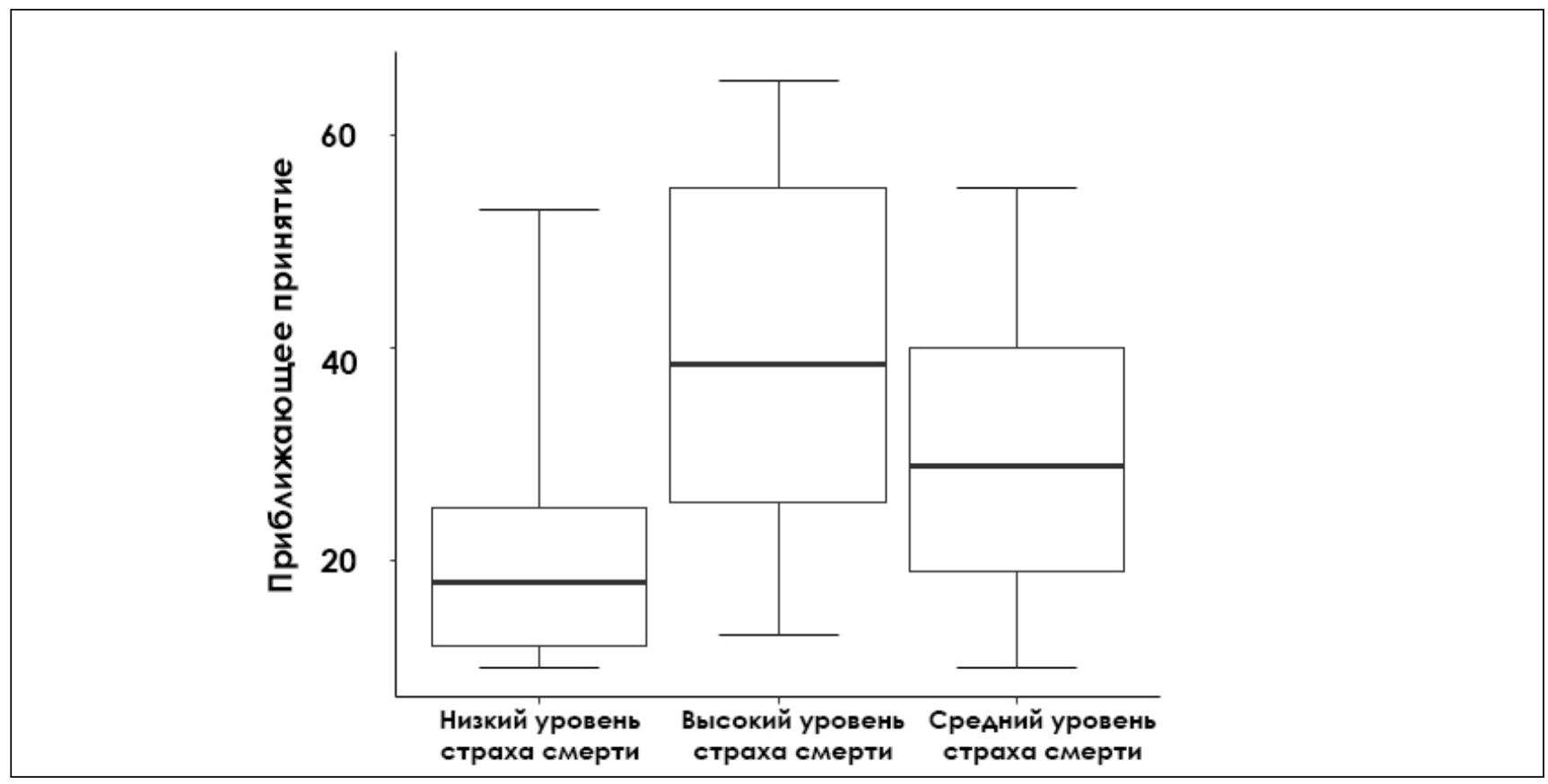

Рисунок 4. Аиаграмма размаха результатов по шкале «приближающее принятие»у групп с разным уровнем страха смерти

Условные обозначения: — - медиана; $\square-25-75 \% ;\rceil$ - минимальные и максимальнье значения.

Люди со средним уровнем страха смерти по исследуемым характеристикам наиболее приближены к людям с низкими показателями страха. Отличие наблюдается в более низких показателях по шкалам «беспокойство о будущем» и «локус контроля - Я», а также во всех шкалах, характеризующих отношение к смерти, где показатели по шкалам «избегание темы смерти», «приближающее принятие» и «избегающее принятие» повышены, а по шкале «нейтральное принятие»-понижены.

Люди с низким уровнем страха смерти характеризуются значимо более высокими показателями по уровню жизненной включенности и осмысленности жизни и входят в совокупность нормативных показателей, выявленных авторами методик. Значения среднего арифметического, стандартного отклонения и медианы этих и других шкал представлены в таблице 2. 
ДМИТРИЕВА П. Р.

СМЫСЛОЖИЗНЕННЫЕ ОРИЕНТАЦИИ У ЛЮДЕЙ С РАЗНЫМ УРОВНЕМ СТРАХА СМЕРТИ

РОССИЙСКИЙ ПСИХОЛОГИЧЕСКИЙ ЖУРНАЛ, 2020, Т. 17, № 3, 5-17. doi: 10.21702/rpj.2020.3.1

ОБЩАЯ ПСИХОЛОГИЯ, ПСИХОЛОГИЯ ЛИЧНОСТИ, ИСТОРИЯ ПСИХОЛОГИИ

\begin{tabular}{|c|c|c|c|c|c|c|c|c|c|}
\hline \multicolumn{10}{|l|}{ Таблица 2} \\
\hline \multirow{2}{*}{ Шкa^a } & \multicolumn{3}{|c|}{$\begin{array}{l}\text { Низкий уровень } \\
\text { страха смерти }\end{array}$} & \multicolumn{3}{|c|}{$\begin{array}{l}\text { Средний уровень } \\
\text { страха смерти }\end{array}$} & \multicolumn{3}{|c|}{$\begin{array}{l}\text { Высокий уровень } \\
\text { страха смерти }\end{array}$} \\
\hline & $\overline{\mathrm{M}}$ & $\sigma$ & $\mathrm{Me}$ & $\overline{\mathrm{M}}$ & $\sigma$ & Me & $\overline{\mathrm{M}}$ & $\sigma$ & $\mathrm{Me}$ \\
\hline $\begin{array}{l}\text { Жизненная } \\
\text { вкАюченность }\end{array}$ & 5,95 & 2,25 & 6 & 5,65 & 2,32 & 6 & 4,44 & 2,18 & 5 \\
\hline $\begin{array}{l}\text { Разочарование } \\
\text { в жизни }\end{array}$ & 5,73 & 1,74 & 6 & 5,11 & 2,12 & 5 & 4,72 & 2,30 & 4,5 \\
\hline Уста^ость от жизни & 7 & 2,38 & 8 & 6,72 & 2,37 & 8 & 5,84 & 2,55 & 5 \\
\hline $\begin{array}{l}\text { Беспокойство } \\
\text { о будущем }\end{array}$ & $\underline{6,57}$ & 1,77 & 6 & $\underline{5,57}$ & 1,87 & 5 & 4,56 & 2,11 & 4,5 \\
\hline $\begin{array}{l}\text { Общая } \\
\text { уАОв^етворенность }\end{array}$ & 6,46 & 1,98 & 7 & 5,76 & 2,20 & 6 & 4,56 & 2,30 & 4 \\
\hline Цель & 31,76 & 7,54 & 32 & 30,01 & 6,17 & 30 & 26,63 & 5,26 & 27 \\
\hline Процесс & 29,97 & 6,75 & 31 & 28,28 & 6,22 & 29 & 26,31 & 5,24 & 25,5 \\
\hline Результат & 25,76 & 5,41 & 26 & 24,2 & 4,70 & 24 & 23,03 & 3,75 & 23 \\
\hline ^окус контроля-Я & $\underline{21,59}$ & 4,00 & 22 & $\underline{19,85}$ & 3,84 & 20 & 17,28 & 3,41 & 17 \\
\hline ^окус контроля-жизнь & 32,03 & 5,86 & 33 & 30,09 & 5,72 & 31 & 27,72 & 4,87 & 28 \\
\hline Осмысленность жизни & 103,32 & 19,27 & 104 & 97,96 & 15,85 & 96 & 89,50 & 13,63 & 85 \\
\hline Страх смерти & $\underline{13,49}$ & 2,78 & 14 & $\underline{25,87}$ & 4,41 & 27 & $\underline{38,78}$ & 4,14 & 38 \\
\hline $\begin{array}{l}\text { Избегание темы } \\
\text { смерти }\end{array}$ & $\underline{11,92}$ & 7,35 & 10 & 17,53 & 7,39 & 17 & 23,13 & 8,23 & 24,5 \\
\hline Нейтральное принятие & $\underline{31,51}$ & 3,88 & 32 & $\underline{28,34}$ & 4,94 & 29 & 28,22 & 4,20 & 29 \\
\hline $\begin{array}{l}\text { Приближающее } \\
\text { принятие }\end{array}$ & $\underline{20,27}$ & 10,38 & 18 & $\underline{29,54}$ & 12,14 & 29 & 39,91 & 16,17 & 38,5 \\
\hline $\begin{array}{l}\text { Избавляющее } \\
\text { принятие }\end{array}$ & $\underline{12,95}$ & 7,48 & 10 & 15,86 & 5,83 & 16 & 17,72 & 8,15 & 17,5 \\
\hline \multicolumn{10}{|c|}{$\begin{array}{l}\text { Примечание: разными типами шрифта обозначены обнаруженные значимые различия межАу } \\
\text { группами - полужирным шрифртом обозначены обнаруженные значимые различия с группой } \\
\text { с низким уровнем страха смерти; подчеркнутым шрифртом обозначены обнаруженные значимые } \\
\text { различия с группой со средним уровнем страха смерти; курсивным шрифртом обозначены } \\
\text { обнаруженные значимые различия с группой с высоким уровнем страха смерти. }\end{array}$} \\
\hline
\end{tabular}


ДМИТРИЕВА П. Р.

СМЫСЛОЖИЗНЕННЫЕ ОРИЕНТАЦИИ У ЛЮДЕЙ С РАЗНЫМ УРОВНЕМ СТРАХА СМЕРТИ

РоссиЙскИй пСИХОЛОГИЧЕСКИЙ ЖУРнАл, 2020, Т. 17, № 3, 5-17. doi: 10.21702/rpj.2020.3.1

ОБЩАЯ ПСИХОЛОГИЯ, ПСИХОЛОГИЯ ЛИЧНОСТИ, ИСТОРИЯ ПСИХОЛОГИИ

\section{Обсуждение результатов}

Приведенные данные показывают взаимосвязь между страхом смерти и осмысленностью и удовлетворенностью жизнью. Согласно полученным данным, низкий уровень страха смерти соответствует большей жизненной включенности, целеустремленности, удовлетворенности процессом и результатом, уверенности в возможности управлять своей жизнью. В таком случае ведущим типом отношения к смерти является нейтральное принятие как признание и принятие человеком факта конечности собственного существования.

Высокий уровень страха смерти, напротив, соответствует меньшей удовлетворенности жизнью, меньшей включенности и осмысленности со сниженным уровнем беспокойства о будущем, что можно трактовать как отсутствие смысла и, соответственно, тревожных переживаний по поводу его реализации. Эти данные согласовываются с результатами исследования Bolt (1978), где была выявлена отрицательная корреляция между танатической тревогой и стремлением к смыслу жизни. Схожие данные мы встречаем и у П. Т. П. Вонга, который говорит о том, что наличие субъективного смысла жизни снижает уровень страха смерти (Wong, 2013). Ведущим типом отношения к смерти в этой группе людей, помимо страха, является приближающее принятие как вера в жизнь после смерти. Этот факт подтверждает мнение Feifel \& Branscomb (1973) и Желателева (2016) о том, что вера в загробную жизнь способствует невротизации, и, напротив, опровергает позицию Корнева и Смирнова (2018) о том, что одним из самых сильных методов борьбы со страхом смерти является вера в жизнь после смерти. Результаты проведенного нами исследования показывают, что вера в загробную жизнь не способствует преодолению страха и повышению уровня удовлетворенности и осмысленности жизни.

Таким образом, отношение к смерти напрямую связано с удовлетворенностью и осмысленностью жизни. Этот факт может иметь большое практическое значение в психокоррекционных мероприятиях, в связи с чем показывает необходимость дальнейшего исследования отношения к смерти.

\section{Литература}

Абакумова, И. В., Ермаков, П. Н. и Рудакова, И. А. (сост.). (2014). Общая теория смысла, психологические концепции смыслообразования, смыслодидактика. Хрестоматия. Москва: КРЕДО.

Абдулгалимова, С. А. (2011). Понятие смысла жизни и смысложизненных парадигм. Вестник Социально-педагогического института, 2, 83-92.

Абульханова-Славская, К. А. (1991). Стратегия жизни. Москва: Мысль.

Андриевская, Г. В. (2017). Образ смерти: религиозный аспект. Вестник науки и образования, 2(6), 115-118.

Арьес, Ф. (1992). Человек перед лицом смерти (В. К. Ронин, пер. с фр.). Москва: Прогресс, Прогресс - Академия.

Баканова, А. А. (2015). Отношение к жизни, смерти и болезни ВИЧ-инфицированных 20-30 лет. Медицинская психология в России: электрон. науч. журн., 2, 4. Доступ 15 мая 2020, источник http://mprj.ru

Гаврилова, Т. А. (2011). Об адаптации опросника «Профиль аттитьюдов по отношению к смерти - переработанный» (DAP-r), разработанного П. Т. П. Вонгом, Г. Т. Рикером и Дж. Гессер. Теоретическая и экспериментальная психология, 4(1), 46-57. 
ДМИТРИЕВА П. Р.

СМЫСЛОЖИЗНЕННЫЕ ОРИЕНТАЦИИ У ЛЮДЕЙ С РАЗНЫМ УРОВНЕМ СТРАХА СМЕРТИ

Российский психологИЧЕский ЖУРнАл, 2020, Т. 17, № 3, 5-17. doi: 10.21702/rpj.2020.3.1

ОБЩАЯ ПСИХОЛОГИЯ, ПСИХОЛОГИЯ ЛИЧнОСтИ, ИстОРИЯ ПСИхОЛОГИИ

Гнездилов, А. В. (2002). Психология и психотерапия потерь. Пособие по паллиативной медицине для врачей, психологов и всех интересующихся проблемой. Санкт-Петербург: Речь.

Горьковая, И. А. и Баканова, А. А. (2014). Осознаваемые компоненты страха смерти в зрелом возрасте. Вестник Ленинградского государственного университета имени А. С. Пушкина, 5(3), 29-39.

Гроф, С. (2002). Человек перед лицом смерти. Тексты трансперсональной психологии. Москва: АСТ.

Желателев, Д. В. (2016). Представления о жизни и смерти и социально-психологическая адаптация личности. В XX Юбилейные Царскосельские чтения (с. 214-220). Санкт-Петербург: Ленинградский государственный университет им. А. С. Пушкина.

Кленина, Е. А. и Песков, А. Е. (2015). Отношение к смерти как условие формирования различных типов культуры. Вестник Астраханского государственного технического университета, 1, 73-77.

Корнев, С. А. и Смирнов, В. В. (2018). Смысл жизни и страх смерти с точки зрения субъект-объектного подхода. Вестник Костромского государственного университета. Серия: Педагогика. Психология. Социокинетика, 24(3), 57-61.

Коромыслов, В. В. (2019). Подход к пониманию смысла жизни с позиции конкретно-всеобщей теории развития. Вестник Вятского государственного университета, 3, 45-53. doi: 10.25730/VSU.7606.19.034

Кукина, М.В.(2015). Взаимосвязь отношения к смерти и ценностно-смысловых характеристик сотрудников хосписа. Бюллетень ВСНЦ СО РАMН, 4, 58-62.

Кюблер-Росс, Э. (2001). О смерти и умирании (К. Семенов, В. Трилис, пер. с англ.). Москва; Киев: София.

Леонтьев, Д. А. (2003). Психология смысла: природа, строение и динамика смысловой реальности (2-е изд.). Москва: Смысл.

Леонтьев, Д. А. (2006). Тест смысложизненных ориентаций (СЖО) (2-е изд.). Москва: Смысл.

Липецкий, Н. Н. (2013). Танатическая тревога и смысложизненные ориентации аутоагрессивной личности. В Г. А. Кайнова (отв. ред.), Психология: проблемы практического применения: Материалы II Международной научной конференции (с. 55-63). Казань: Издательство Молодой ученый.

Мельникова, Н. Н. (2004). Диагностика социально-психологической адаптации личности: учебное пособие. Челябинск: Изд-во ЮУрГУ.

Мохов, С. В. (2016). Ситуация с «death studies» в современной науке. Новое прошлое / The New Past, 4, 229-236.

Пинегина, Н. М. (2017). Отношение к смерти больных сахарным диабетом с разной жизненной стратегией. Личность в меняющемся мире: здоровье, адаптация, развитие: сетевой журн., 4(1), 72-78. doi: 10.23888/humJ2017172-78

Солдатова, Е. Л. и Жукова, Н. Ю. (2018). Теоретический обзор современных зарубежных исследований отношения к смерти. Вестник Южно-Уральского государственного университета. Серия: Психология, 11(3), 13-23. doi: 10.14529/psy180302

Фейфел, Г. (2001). Смерть - релевантная переменная в психологии. В Р. Мэй (ред.), Экзистенциальная психология = Existential psychology (М. Занадворов, Ю. Овчинникова, пер. с англ.) (с. 28-34). Москва: Апрель Пресс, ЭКСМО-Пресс.

Франкл, В. (1990). Человек в поисках смысла. Москва: Прогресс. 
ДМИТРИЕВА П. Р.

СМЫСЛОЖИЗНЕННЫЕ ОРИЕНТАЦИИ У ЛЮДЕЙ С РАЗНЫМ УРОВНЕМ СТРАХА СМЕРТИ

РоссиЙскИй пСИХОЛОГИЧЕСКИЙ ЖУРнАл, 2020, Т. 17, № 3, 5-17. doi: 10.21702/rpj.2020.3.1

Фромм, Э. (2006). Бегство от свободы. Человек для себя. Москва: АСТ.

Чистопольская, К. А., Ениколопов, С. Н., Николаев, Е. Л., Семикин, Г. И., Храмелашвили, В. В., Казанцева, В. Н. и Журавлева, Т. В. (2014). Адаптация опросников «Отношение к смерти» и «Страх личной смерти» на русскоязычной выборке. Суицидология, 5(2), 60-69.

Bolt, M. (1978). Purpose in life and death concern. The Journal of Genetic Psychology, 132(1), 159-160. doi: $10.1080 / 00221325.1978 .10533327$

Feifel, H., \& Branscomb, A. B. (1973). Who's afraid of death? Journal of Abnormal Psychology, 81(3), 282-288. doi: 10.1037/h0034519

Greenberg, J., Pyszczynski, T., \& Solomon, S. (1986). The causes and consequences of a need for self-esteem: A terror management theory. In R. F. Baumeister (Ed.), Public self and private self (pp. 189-212). New York: Springer. doi: 10.1007/978-1-4613-9564-5 10

Harding, S. R., Flannelly, K. J., Weaver, A. J., \& Costa, K. G. (2005). The influence of religion on death anxiety and death acceptance. Mental Health, Religion \& Culture, 8(4), 253-261. doi: 10.1080/13674670412331304311

Hayes, J., Ward, C. L. P., \& McGregor, I. (2016). Why bother? Death, failure, and fatalistic withdrawal from life. Journal of Personality and Social Psychology, 110(1), 96-115. doi: 10.1037/ pspp0000039

Nazarzadeh, M., Sarokhani, M., \& Sayehmiri, K. (2015). The relationship between religious attitudes, fear of death and dying with general health condition: A survey in college students. Journal of Religion and Health, 54, 1672-1680. doi: 10.1007/s10943-014-9903-6

Wong, P. T. P., Reker, G. T., \& Gesser, G. (1994). Death Attitude Profile-Revised: A multidimensional measure of attitudes toward death. In R. A. Neimeyer (Ed.), Death anxiety handbook: Research, instrumentation, and application (pp. 121-148). Washington, DC: Taylor \& Francis.

Wong, P. T. P. (2013). Meaning management theory and death acceptance. In A. Tomer, G. T. Eliason, \& P. T. P. Wong (Eds.), Existential and spiritual issues in death attitudes (pp. 91-114). Psychology Press.

Конфликт интересов отсутствует 